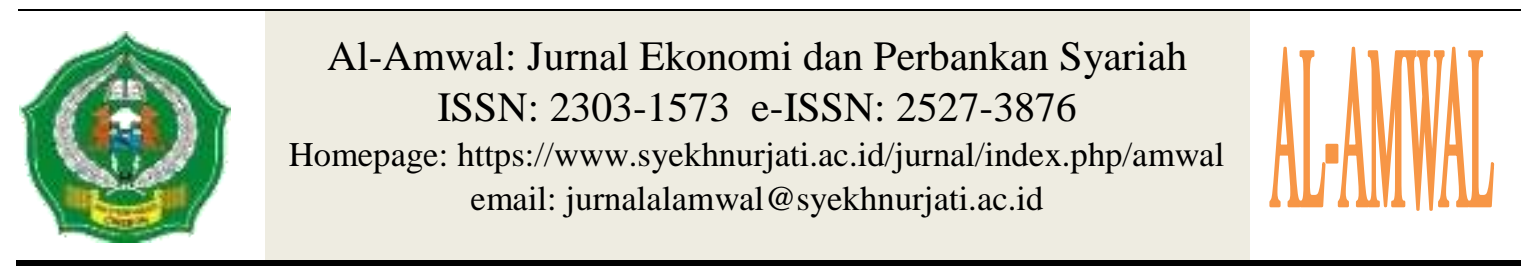

\title{
Preparation of PSAK 109 ZIS Financial Statements Using Excel for Accounting for the Nurul Huda Jatiseeng Mosque
}

\author{
Yekti Nilasari ${ }^{1 *}$ \\ Rosidin ${ }^{2}$ \\ ${ }^{1,2}$ Universitas Nahdlatul Ulama Cirebon \\ e-mail: nila_sardono@yahoo.com*
}

\begin{abstract}
Management of zakat requires a good accounting system and order in financial administration as well as an adequate management information system so that zakat infaq alms can be managed properly to be distributed properly to mustahiq. The fundamental problem that is often faced by managers of zakat infaq alms is standardization in the accounting system and auditing of financial statements. There are still many zakat or amil administrators who have not been able to implement their financial reporting in accordance with PSAK 109 regarding zakat accounting, infaq/alms, especially zakat amil bodies operating within the scope of villages or mosques, where they still use manual calculations. The purpose of this study is to provide an overview of the application of PSAK 109 which should be used to prepare financial reports for zakat, infaq and alms with the help of using the Microsoft Excel application. The purpose of this study is to apply the presentation of financial statements that are accountable and transparent so that they can provide performance information and financial reports to internal and external parties.

This research is a qualitative descriptive study which explains the implementation of PSAK 109 application by using excel application for accounting. This study resulted in a quantitative data input model for zakat finance using the Microsoft excel application in compiling financial reports for zakat, infaq / alms in accordance with PSAK 109.
\end{abstract}

Keywords: PSAK 109, Microsoft Excel for Accounting

\begin{abstract}
Abstrak
Pengelolaan zakat memerlukan sistem akuntansi yang baik dan ketertiban dalam administrasi keuangan serta sistem informasi manajemen yang memadai agar zakat infaq sedekah dapat dikelola dengan benar untuk disalurkan dengan tepat kepada mustahiq. Permasalahan mendasar yang sering dihadapi pengelola zakat infaq sedekah adalah standarisasi dalam
\end{abstract}


sistem akuntansi dan audit laporan keuangan. Pengurus zakat atau amil masih banyak yang belum dapat menerapkan pelaporan keuangannya sesuai dengan PSAK 109 tentang akuntansi zakat, infaq/sedekah terutama badan amil zakat yang beroperasi dalam lingkup desa atau masjid, yang mana mereka masih menggunakan perhitungan manual. Tujuan dari penelitian ini memberikan gambaran penerapan PSAK 109 yang selayaknya digunakan untuk menyusun laporan keuangan zakat, infaq dan sedekah dengan bantuan menggunakan aplikasi microsoft excel. Tujuan penelitian ini untuk menerapkan penyajian laporan keuangan yang akuntanble dan transparan sehingga dapat memberikan informasi kinerja dan laporan keuangan kepada pihak yang intern dan ekstern.

Penelitian ini merupakan deskriptif kualitatif yang menjelaskan implementasi penerapan PSAK 109 dengan menggunakan aplikasi excel untuk akuntansi. Penelitian ini menghasilkan model penginputan data kuantitatif keuangan zakat dengan menggunakan aplikasi Microsoft excel dalam menyusun laporan keuangan zakat, infaq/sedekah sesuai dengan PSAK 109.

Kata kunci: PSAK 109, Microsoft Excel Untuk Akuntansi

\section{INTRODUCTION}

Zakat management requires a good accounting system and in order to financial administration as well as an adequate management information system so that zakat infaq alms can really be managed properly and correctly to be distributed appropriately to mustahiq. The fundamental problem that is often faced by managers of zakat infaq alms is standardization in the accounting system and auditing of financial statements. There are still many zakat or amil administrators who have not been able to implement their financial reporting in accordance with PSAK 109 regarding zakat accounting, infaq/alms, especially zakat amil bodies operating within the scope of villages or mosques, where they still use manual calculations.

(Rahman, 2015) Correct accounting and reporting systems can help achieve transparency and accountability.(Zakat et al., 2008) PSAK 109 regarding accounting for zakat infaq/shadaqah has been made by IAI and ratified precisely on April 6, 2010, but there are still many BAZ/LAZ that have not implemented it properly, while having a good accounting and financial system is one of the factors that will increase public trust . An accounting system that has a clear source and use of zakat funds is expected to be more effective, efficient and more transparent and accountable.

Nurul Huda Mosque in Jatiseeng has not implemented financial statements in accordance with the Statement of Financial Accounting Standards (PSAK) because of the reason, the researchers want to conduct research with the Implementation of PSAK 109 on Zakat Infaq Financial Reporting by using excel applications for accounting. (Hamizar, 2012) Program Excel for Accounting (EFA) is a computer application program that can be used to process data and present company financial reports. With EFA, financial data can be processed quickly and accurately, thereby saving time, activities and company operational activities. Many applications are a means of preparing financial reports, but using Microsoft Excel for Accounting is suitable for companies that have never made financial reports before, and the 
possibility of errors in this application is smaller than other applications. Although there is a possibility of errors in recording transactions, in this application users can immediately delete previous errors, and correct them again without having to delete related transactions, and Microsoft Excel for Accounting will refresh so the table will be updated automatically. Preparation of financial reports using Microsoft Excel for Accounting will make it easier for companies because the format is equipped with formulas.

Formulation of the problem

1. How to Apply PSAK No. 109 to reports on zakat, infaq and alms at Nurul Huda Mosque, Jatiseeng

2. Have the Microsoft excel application used for accounting at the Nurul Huda Jati Mosque?

Research purposes

Implementing zakat, infaq and alms accountability reports based on PSAK No. 109 with excel operations for accounting

\section{LITERATURE REVIEW}

Zakat Infaq and Sadaqah

Zakat is a wealth that must be issued by a Muslim or business entity to be given to those who are entitled to receive it in accordance with Islamic law (UU No 23 RI, 2011).

Zakat is self and wealth cleaning from the possibility of being obtained by illegal means. Paying zakat will also make wealth grow and develop. A person who pays zakat because of his faith will certainly get a lot of goodness. Allah SWT said, "Take zakat from some of their wealth with zakat you clean and purify them".(QS AT Taubah 103, n.d.)

The purpose of zakat is not only to support the poor consumptively, but also to reduce poverty and raise the status of the poor by helping them out of life's difficulties. Zakat is an amaliyah worship which has socio-economic dimensions and functions as well as social solidarity as well as removing the gap that separates the rich and the poor. (Wulansari \& Setiawan, 2014)

Infaq is removing part of the wealth owned for interests that contain benefits. In infaq there is no nishab. That's why infaq may be issued by people who have high or low income, when they are spacious or narrow (Surat Ali Imran 134, n.d) Infaq means removing part of the property or income or income for an interest that is commanded by the Islamic religion. Infaq can be done by anyone, (Muhammad sanusi, 2009)

Sadaqah is a gift from a Muslim voluntarily without being limited in time and amount (haul and ratio) as a favor with the hope of Allah's blessing. (M Irfan Firdausy, 2002)

\section{Accounting Cycle}

Accounting is the activity of collecting, analyzing, presenting in the form of numbers, classifying, recording, summarizing, and reporting company activities/transactions in the form of financial information. (Rudianto, 2012).

Accounting plays an important role in the entity because accounting is the language of business. (Ati Retna Sari, Delia Nurbatin, 2017). It can be concluded that accounting produces information on the financial performance of the entity in a certain period and also informs the financial condition of the entity.

With accounting used as accountability, accounting becomes a tool or stewardship 
function where the information presented demands that it has real, true, objective, and reliable quality. (Sofyan Syafri Harahap, 2011)

The accounting cycle is a sequence of work that must be carried out by accountants from the beginning to produce financial statements (Rudianto, 2012).

(Herry, 2014) The stages of the accounting cycle are as follows:

1. Transaction supporting documents are analyzed and the information contained in these documents is recorded in a journal

2. We post the accounting data in the journal into the general ledger

3. All ending balances in each general ledger account are transferred to the trial balance

4. Analyze adjusting data and make adjusting entries

5. Posting adjusting journal data to the respective general ledger accounts

6. (Optional) may use the help of working papers (balance sheet)

7. Prepare financial reports

8. Closing journal entry

9. Trial after closing

10. Reverse journal verse

\section{Sharia Accounting}

Sharia accounting is a rule that has been set by Allah Subhanahu Wa Ta'Ala to be obeyed by humans in carrying out all their life activities in the world. Sharia accounting is an accounting process for transactions in accordance with the rules set by Allah Subhanahu Wa ta'Ala. Sharia accounting is needed for the implementation of sharia and there is a need due to the rapid development of sharia transactions. (Wasilah dan Sri Nurhayati, 2017)

\section{Preparation of Financial Statements with Microsoft Excel for Accounting}

Microsoft Excel is software for processing data automatically including basic calculations, use of functions, make a graph, and data management. This software is very helpful for solving administrative problems ranging from simple to more complex. Microsoft Excel is a spreadsheet application program created and distributed by Microsoft Corporation for the Microsoft Windows operating system (Hamizar, 2012)

The bigger a company or institution, the more and more complex the accounting data that must be processed. For this reason, suggestions are needed to process accounting information quickly, precisely, and accurately. One of them is simply by using computer media by utilizing the Microsoft excel program which can be used to process accounting data cycles. (Ministry of Finance.

The quality of financial reports produced by each institution must meet several quality standards, including: understandable, relevant, material, reliable, complete. Comparable, and timely (Rudianto, 2012)

\section{Account (Estimated)}

The accounting system is designed to show the increase and decrease in the balance of each component of the financial statements and must be recorded in detail and separately for each component of the financial statements (Herry, 2014).

Account is a tool for recording financial transactions related to assets, liabilities, capital, income and expenses (Yusuf, 2017). 


\section{Preparation of Financial Statements}

At the end of the accounting cycle, the company's accountants must make financial statements, information from these financial statements is made for various parties who need it. (Rudianto, 2012) explained that the financial statements made must comply with the applicable standards in Indonesia, namely financial accounting standards.

(Sofyan Syafri Harahap, 2011) states that the purpose of financial statements is to provide information regarding the financial position, performance, and changes in financial position of an enterprise that is useful to a wide range of users in decision making.

Financial reports that need to be made by the Zakat Infaq Sedekah institution or the Amil Zakat Agency are financial reports that are guided by PSAK 109.

(IAI, 2010) The purpose of Statement of Financial Accounting Standards Number 109 is to regulate the recognition, measurement, presentation and disclosure of zakat and infaq/alms transactions.

\section{Accounting for Zakat, Infaq/Shadaqoh}

Accounting is the art of recording, classifying, summarizing, interpreting, and communicating in a certain way and in monetary terms, transactions and economic events of a legal or social entity (Kieso, 2010)

Sharia accounting is a rule that has been set by Allah Subhanahu Wa Ta'ala to be obeyed by humans in carrying out all their life activities in the world, so sharia accounting is an accounting process for transactions in accordance with the rules set by Allah Subhnahu Wa Ta'Ala.(Wasilah dan Sri Nurhayati, 2017)

(IAI, 2012) PSAK 109 Regarding Reporting in Accounting for Zakat and Infaq/Alms, there are several definitions used in statements in accordance with Statement of Financial Accounting Standards No. 109. Statement of Financial Accounting Standards 109 regulates the recognition and measurement and presentation of Zakat, Infaq/Shadaqoh Funds with components of financial statements in PSAK No. These 109 are: Balance Sheet (Statement of Financial Position), Report on Changes in Funds, Report on Changes in Assets Under Management, Statement of Cash Flows, and Notes on Financial Statements.

(Law No. 23 RI, 2011)explained that there are two zakat management organizations authorized to manage zakat in Indonesia, namely the National Amil Zakat Agency and the Amil Zakat Institution. The National Amil Zakat Agency is a Zakat Management Organization established by the government.

(IAI, 2010) PSAK 109 explains Zakat and Infaq/Alms received by amil must be managed in accordance with sharia principles and good governance. Infaq/Alms funds are funds originating from infaq/alms receipts. Zakat funds are funds originating from zakat receipts. Infaq/alms are assets that are given voluntarily by the owner, whether the designation is determined or not. (Muhajirin, 2020) The lack of supervision carried out in the management of ZIS makes the management prone to deviations which makes the management process unable to run in accordance with the provisions so that it becomes one of the obstacles in the management process carried out.

(IAI, 2010) PSAK No. 109 states that Mustahik (Mustahiq) is a person or entity entitled to receive zakat. Mustahik consists of: Fakir, Poor, Riqab, People in debt (Gharim), Converts, Fisabilillah, People on the way (Ibn Sabil), and Amil. Muzaki (Muzakki) are Muslim individuals who are shariah obligated to pay or pay zakat. 
(IAI, 2010) PSAK 109:09 Initial Recognition, zakat receipts are recognized when cash or other assets are received.

PSAK 109:10: Zakat received from muzakki is recognized as an addition to zakat funds if it is in the form of cash, it is the amount received and if it is in the form of noncash, it is the fair value of the non-cash asset.

PSAK 109 : 11 determination of the fair value of non-cash assets received using the market price, if the market price is not available then other fair value determination methods can be used as stipulated in the relevant PSAK.

PSAK 109: 15 If there is a decrease in the value of non-cash zakat assets, the amount of loss incurred must be treated as a deduction from zakat funds or a deduction from amil funds depending on the cause of the loss. Infaq / alms received are recognized as bound or unbound infaq / alms funds according to the purpose of the infaq / alms given amount received if it is in the form of cash and fair value if it is in the form of noncash. PSAK 109: 20 infaq/alms received can be in the form of cash or non-cash assets. Non-cash assets can be in the form of current and non-current assets (IAI, 2010)109.13 Illustration of Report on Changes in Amil Zakat Agency Funds

Amil presents reports on changes in zakat funds, infaq/alms funds, amil funds, and non-halal funds. The presentation of the change in funds report includes, but is not limited to the following items

Fund Change Report

BAZ "XXX"

For the Period Ended 31 December 2xx2

$\begin{array}{ll}\text { ZAKAT FUND } & \\ \text { Reception } & \\ \text { Acceptance From Muzakki } & \text { xxx } \\ \text { Muzakki Entity } & \text { xxx } \\ \text { Muzakki individual } & \text { xxx } \\ \text { Placement Result } & \text { xxx } \\ \text { Total Zakat Fund Receipt } & \underline{\mathrm{xxx}} \\ \text { Share amil for the Zakat Fund Receipt } & \mathrm{xxx}\end{array}$

\section{Distribution}

Poor

Riqab

Gharim

Muallaf

Sabilillah

Total Distribution of Zakat Funds 
INFAQ.SEDEKAH FUND

Reception

Infaq/tied alms or muqayyadah $\quad$ xxx

Infaq / Alms is not bound or mutlaqah $\quad \mathrm{xxx}$

Amil's share of receiving infaq/alms funds $\quad$ (xxx)

Management Result $\quad \underline{\mathrm{xxx}}$

Total Receipt of infaq / alms $\quad$ Xxx

Distribution

infaq/tied alms or muqayyadah $\quad$ (xxx)

infaq/alms are not bound or mutlaqah $\quad$ (xxx)

Allocation of utilization of assets under management $\underline{(\mathrm{xxx})}$

(eg depreciation expense and allowance)

Amount of disbursement of infaq/alms funds $\quad$ (xxx)

Surplus (deficit) $\quad$ Xxx

Starting Balance $\underline{\mathrm{xxx}}$

Final Balance $\quad \mathrm{xxx}$

AMIL FUND

Reception

Amyl's share of zakat funds $\quad$ xxx

Amyl's share of infaq/sadaqa funds $\quad x x x$

Other receptions $\quad \underline{\mathrm{Xxx}}$

Amil funds received $\quad \frac{\mathrm{xxx}}{\mathrm{xxx}}$

Use

Employee expenses $\quad$ (xxx)

Depreciation expense (xxx)

General and other administrative expenses $\underline{(\mathrm{xxx})}$

Total usage and amyl $\quad$ (xxx)

Surplus (deficit) $\quad$ xxx

Starting Balance $\quad \underline{\mathrm{xxx}}$

Final balance $\quad \frac{\mathrm{xxx}}{\mathrm{xxx}}$

NON-HALAL FUND

Reception

bank interest $\quad \mathrm{xxx}$

Checking services $\quad$ Xxx

Other non-halal receipts $\quad \underline{\mathrm{xxx}}$

Total non-halal funds received $\quad \mathrm{xxx}$

Use

Total use of non-halal funds $\quad$ (xxx)

Surplus (deficit) $\quad$ xxx

Starting balance $\quad$ xxx

Final balance $\quad$ xxx 


\title{
Illustration of Statement of Financial Position (Balance Sheet)
}

\author{
Balance Sheet (Statement of Financial Position) \\ BAZ 'XXX' \\ As of 31 December $2 \times x 2$
}

\author{
ASSET \\ Current asset \\ Cash And Cash Equivalents \\ Financial Instruments \\ XXX \\ Receivables \\ Non-Current Assets \\ Fixed Assets \\ Accumulated Depreciation \\ $(\mathrm{XXX})$
}

Total Assets

XXX

\section{LIABILITIES}

Short Term Liabilities

Accrued Fees

XXX

Long-term Liabities

Long-term employee benefits

XXX

Total Liabilities

$\mathrm{XXX}$

FUND

Zakat Fund

$\mathrm{XXX}$

Infaq/Alms fund

$\mathrm{XXX}$

Amil Funds

$\mathrm{XXX}$

Non-halal funds

Total Funds

$\mathrm{XXX}$

Total Liabilities And Funds

XXX

XXX

Asset Management Change Report

Amil entities present a report on assets under management which includes but is not limited to:

a. Assets under management including current assets

b. Assets under management which include non-current and accumulated depreciation

c. Addition and subtraction

d. Beginning balance

e. Ending balance

Cash flow statement

Amyl entities present a statement of cash flows in accordance with PSAK 2: Statement of Cash Flows and the relevant PSAK

Notes to Financial Statements

Amil presents notes to financial statements in accordance with PSAK 101: Presentation of Sharia Financial Statements and relevant PSAK 


\section{Previous Research}

(Amelia \& Qibtiyah, 2015) stated in the study that PSAK 109 is an accounting standard that was made for accounting for zakat, infaq and alms so that it was prepared with due regard to Islamic sharia.

(Hadijah, 2019) stated that the accounting application of PSAK 109 regulates the recognition, measurement, presentation, and disclosure of zakat, infaq and shadaqah accounting.

Efforts to increase transparency and accountability of zakat management organizations (OPZ) by implementing PSAK No. 109 (Rahman, 2015)

(Elvinda Febry Angraeni, 2016)states that in general the funds received by zakat management organizations cannot be separated from the realization of one's faith about Islamic law. Muzaki/Donors need to know that the flow of funds they submit has been used correctly by reporting performance and financial reports to the muzaki. (Judhia, 2009) accounting applications not only use ready-made applications, but we can make our own using excel.

(Augustin, 2016) states that the presentation of financial statements using Microsoft Excel can be verified by an independent measurer using subjective measurement methods in order to increase the benefits of financial information.

The difference between previous research and researchers is that the researchers here present the financial statements of PSAK 109 by utilizing Microsoft Excel for the accounting cycle so as to facilitate the preparation of zakat, infaq and shadaqoh accounting financial reports. (Di \& Kabupaten, 2021)

(Aditya, 2019) Preparation of non-profit financial reports using Microsoft excel.

The difference between the previous research and the researcher is that the researcher here presents the financial statements of PSAK 109 by utilizing Microsoft Excel for the accounting cycle so as to facilitate the preparation of accounting financial statements for zakat, infaq and shadaqoh.

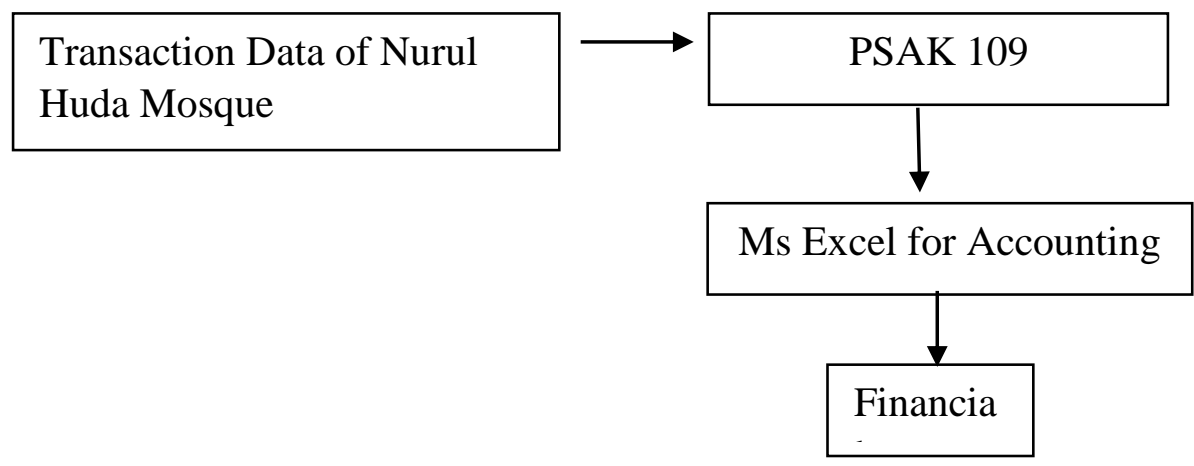

\section{Image 1 \\ Framework of thinking}

\section{RESEARCH METHODS}

(Boedi Abdullah, 2014)The descriptive method applied in Islamic economic problems has several main criteria, namely general and specific. The general criteria for the formulated problem are worthy of research, have scientific value, and are not too broad and stated explicitly not too general.

The research used is descriptive research with data collection carried out by conducting data selection. 
Qualitative research is a systematic and subjective approach used to describe life experiences and give them meaning. The result is expected to be able to gain an understanding of certain phenomena from the perspective of participants who experience the phenomenon(V. Wiratna Sujarweni, 2019). This type of research is a descriptive qualitative approach that explains the implementation of the application of PSAK 109 by using an excel application for accounting and using subject data.

Data and information collection techniques commonly used in qualitative approaches are: observation, in-depth interviews, documentation studies, Focus Group Discussion (FGD), participatory (Rully Indrawan, 2014)

Sources of research data are divided into two: (1) primary data which is research data obtained directly through interviews from the main informants and responses, (2) secondary data is a source of data obtained by reading, studying, and understanding through media, literature, books and documents (Sugiyono, 2019).

The data used are primary data obtained directly from research subjects and secondary data. The research subject is the Nurul Huda Jatiseeng Mosque, Ciledug District, Cirebon Regency. Data collection techniques used are documentation and interview techniques. The expected output data from this research is the accounting financial statements of zakat, infaq and shadaqah based on the Statement of Financial Accounting Standards Number 109.

\section{RESEARCH AND DISCUSSION}

Nurul Huda Jatiseeng Mosque, Ciledug District, Cirebon Regency is a mosque that has many Islamic activities both in terms of education, commemoration of Islamic holidays and one of its activities is the empowerment of zakat, infaq / alms. This mosque is one of the amil zakat institutions / zakat amil institutions that receive, collect and distribute zakat, infaq, and alms.

Nurul Huda Mosque was founded in 1935 with a land area of 970 square meters and a building area of 926 square meters. It is the center of community activities in the religious field. As the organizer of the empowerment of zakat, infaq, and alms at the Nurul Huda mosque, they routinely carry out financial reporting on the collection and distribution of zakat, infaq, alms (ZIS). ZIS reports made are still in manual recording and without the preparation of financial statements.

Nurul Huda Mosque has a capacity of 500 worshipers with 4 priests and 8 preachers who routinely and alternately fill all mosque activities built from waqf land.

The history of its establishment in 1935 - 1950 was still a temporary building, using bamboo and coconut wood curtains, using a booth made of bamboo on stilts made by a local named K. Muhammad Bakri

In 1950-1975 the condition of the building was repaired by K Muhammad Bakri, who then in 1975-1985 the mosque had a Mosque Prosperity Council (DKM) for the management of mosque activities led by Mr. K. Burhan. In 1990-1995, the chairman of DKM was replaced by K. Bisri Imam Gazah, in 1995 - 2000 with the chairman of DKM K. Hisabudan, in $2000=2011$ by K. Ali Imrin, in 2011-2016 the building began to be renovated until 2019.

The source of the funds collected by the Nurul Huda Mosque is from muzakki (zakat givers) who come from ordinary people who come directly to the Nurul Huda Mosque, which are only recorded manually without proof of transactions. In addition to 
receiving funds through muzakki donors, there are funds generated from kencleng or mosque keropak which are calculated every week on Friday.

The distribution of ZIS funds is carried out by handing over funds directly to mustahik and the funds received by the mosque are also used for mosque operations and mosque building renovations.

Financial statements are very important for all entities, not only business entities but organizations or entities in which there are transactions that can be valued in money where financial statements must be prepared as a form of transparency and accountability of an entity.

Based on the data obtained by the researchers in the form of records of receipts and distributions of ZIS in 2020, the researchers tried to compile financial reports based on PSAK 109 for ZIS using the Microsoft excel application.

(Fati GN Larosa \& Beruelektroen br Ginting, 2009) The accounting cycle is a sequence of stages of transactions and events of accounting activities from the beginning to the end of the accounting period continuously starting from (1) the recording stage, namely transaction documents, general journals, ledgers and trial balances, (2) the summarizing stage, namely adjusting journal entries and balance sheets. work sheet and reversing, (3) reporting stage, namely financial statements,

Financial reports that need to be made by the Zakat Infaq Sedekah institution or the Amil Zakat Agency are financial reports that are guided by PSAK 109.

(IAI, 2010) The purpose of the Statement of Financial Accounting Standards Number 109 is to regulate the recognition, measurement, presentation and disclosure of zakat and infaq/alms transactions.

This PSAK applies to amil zakat, which is an organization or entity that manages zakat, infaq/alms whose formation and measurement is regulated based on laws and regulations intended to collect and distribute zakat, infaq/sadaqa funds. PSAK 109 refers to several fatwas of the Indonesian Ulema Council (Wasilah and Sri Nurhayati, 2017) namely MUI Fatwa Number $8 / 2011$ concerning amil zakat, MUI fatwa number 13/2011 concerning zakat law on illicit assets, MUI fatwa number 14/2011 regarding distribution of assets. zakat in the form of assets under management, and MUI fatwa number 15/2011 on withdrawal, maintenance, and distribution.

Amil zakat financial reports can be a medium of communication between amil institutions and other parties, zakat infaq / alms financial reports are a form of operational responsibility from an amil institution that carries out the collection and distribution of zakat funds, infaq / alms. The financial statement information that is made should be accountable and transparent in accordance with the statement of financial accounting standard number 109 which regulates the generally accepted accounting of zakat infaq/sedkah in Indonesia.

The first step that must be made to prepare a financial report is to go through the accounting cycle.

The stages of completing the accounting cycle using Microsoft Excel for accounting.

1. Collect all transaction documents/events that occurred during the period January to December 2020

A transaction is a business event that can be measured using monetary units and that causes a change in one of the elements of the financial position (Rudianto, 2012) 
2. Make account numbering (estimate) and account name (estimate) by opening the Microsoft Excel application and preparing a Microsoft Excel workbook, then changing the name Sheet 1 to Account (Account)

Account is a class of information in the accounting system (Rudianto, 2012)

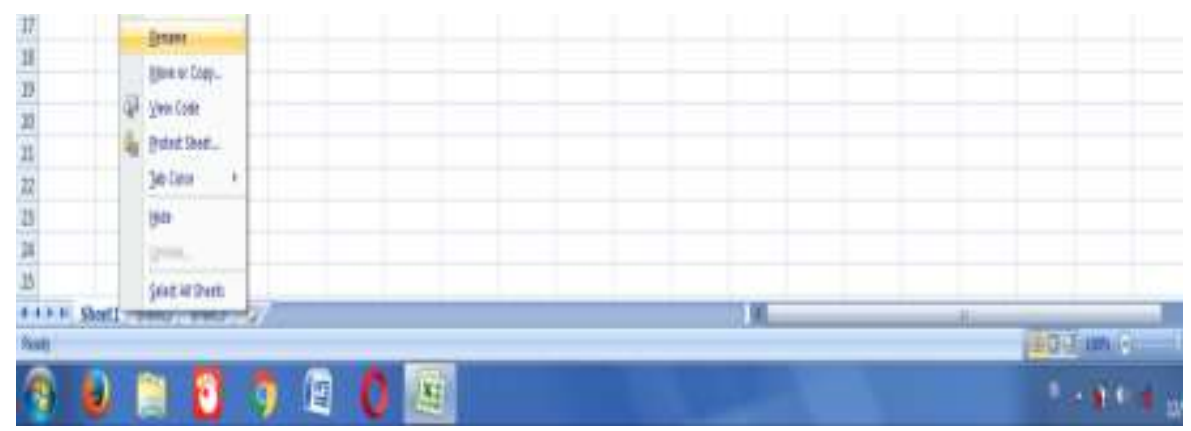

Figure 2 Rename Sheet

3. After the account number and name are typed, then next we give the name of the account range (account) by blocking (without following the column header) then clicking the insert menu, pointing to define and clicking name, typing the name of the account range and then clicking the add button so that the account range (account) enter the list then click close to end

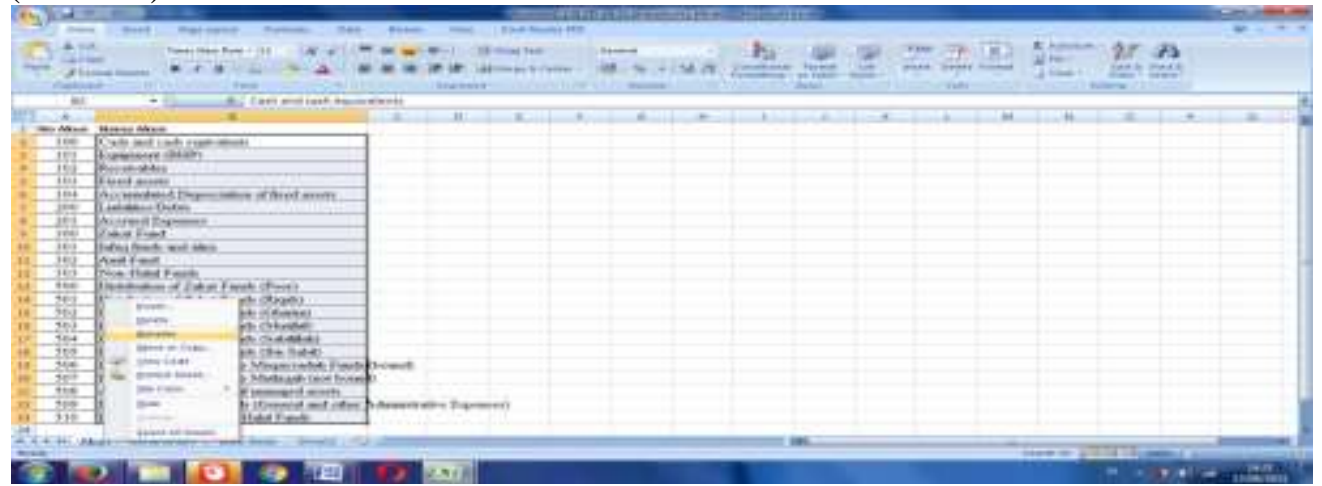

Figure 3 Renaming the Account Sheet

Range names will be very useful for solving cases in the accounting cycle, especially those using the VLOOKUP and SUMIF formulas

4. Take notes to the general journal with the first step opening the excel sheet2 workbook and renaming it to the general journal (see picture)

The general journal is made for transactions outside the special journal (Herry, 2014) 


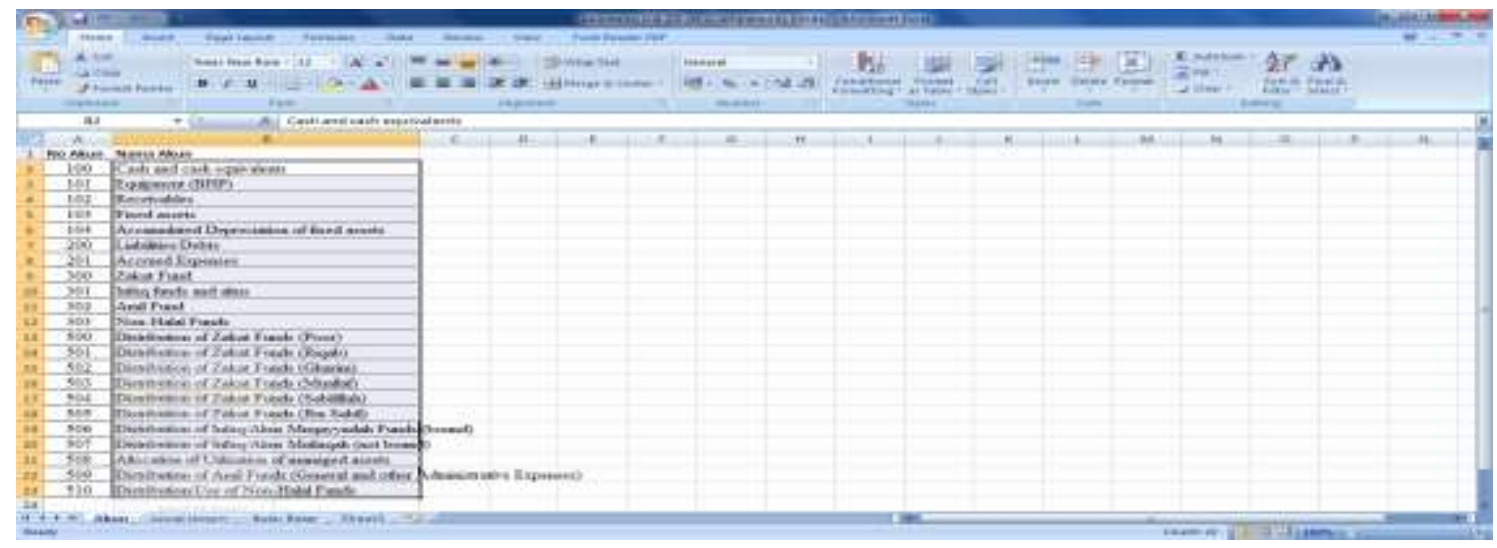

Figure 4 making a general journal sheet

Then the general journal sheet is filled with the title or description with the date column, proof number, account number, account name, debit, credit.

For the account name column, it is not typed normally but by using a formula so that the account name is accurate according to what is on the account sheet Method: place the cursor in the account name column then fill in the formula with

\section{=VLOOKUP $($ C7,Account, 2,0)}

Next, after the formula is entered in cell D7, we copy it so that the name the other accounts will be filled.

view image

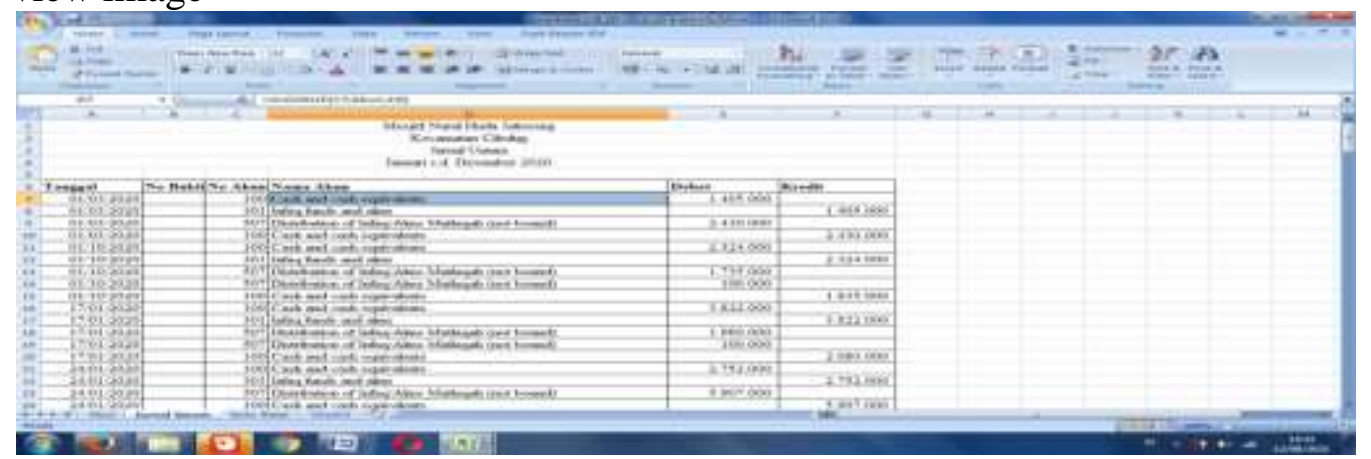

Figure 5 General Journal

5. Creating a Ledger sheet or what is called the process is posting. (Rudianto, 2012)states that the general ledger is a collection of all accounts owned by a company and their balances. And to move the records in the journal to the general ledger, we must post according to the type of transaction and the name of each account.

To make it easier to fill in, we don't need to type one by one, just copy the general journal sheet by right-clicking, clicking Move copy then putting a check mark on create a copy and then clicking OK.

view image 


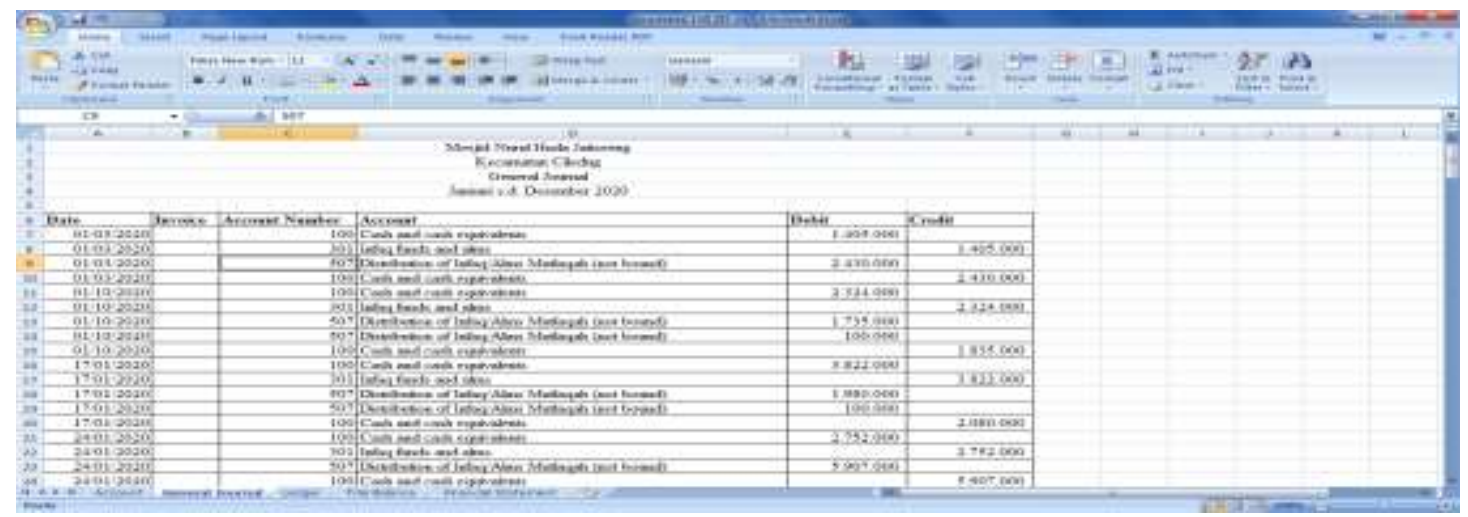

Figure 6 General Journal

Delete the column no evidence and row total by right-clicking on column letter $\mathrm{B}$ and then clicking delete. And also delete the total amount of debits and credits, so that the remaining columns on the ledger sheet are the date column, account number, account name, debit and credit.

\section{Insert initial balance data}

Estimates contained in the beginning balance sheet of the previous period are inserted at the bottom of the general ledger table

\section{Sorting Transactions}

Sorting all transactions from beginning to end by blocking the transaction table in the ledger sheet including the column headers, to the last transaction then click Data, click sort and make your choice

The sort by option is Account Number because all account numbers must be grouped in ascending order.

My list has header row is to indicate that the table in the block is included with the column headers (Fati G N Larosa \& Berupilihen br Ginting, 2009)

After the account numbers are sorted from the smallest to the largest, the account names will be grouped. Each group must be subtotaled by means of a block table from the sort result, including the column header, click the Data menu and then click sub total.

The function used is sum and subtotal will be carried out in the debit and credit column and click the OK button

The results will show the text Total and Grand Total as well as outline symbols namely $1,2,3$ on the upper left side of the screen and the collapse button or expand button ("_" or "“+")

If we click 1 , only the total number of the ledger will appear as shown below 


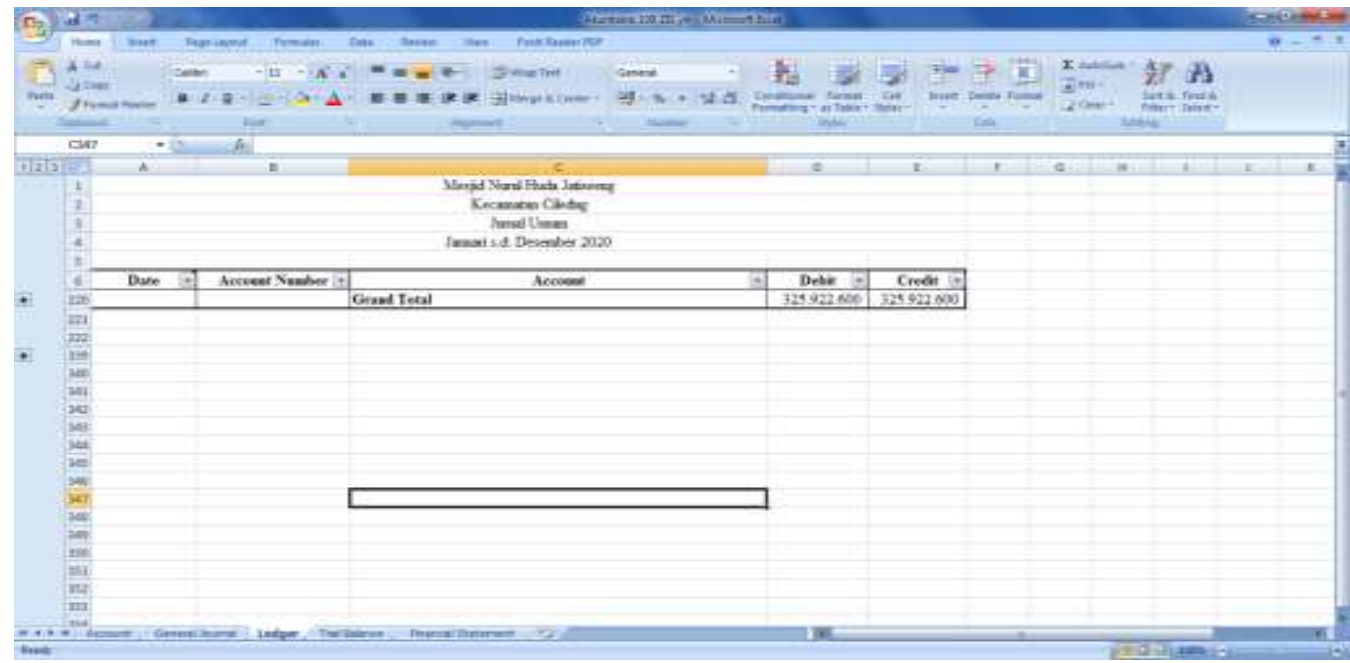

Picture of 7 Ledgers with Outline Symbol 1

If we click 2 then the sub total from per account will appear

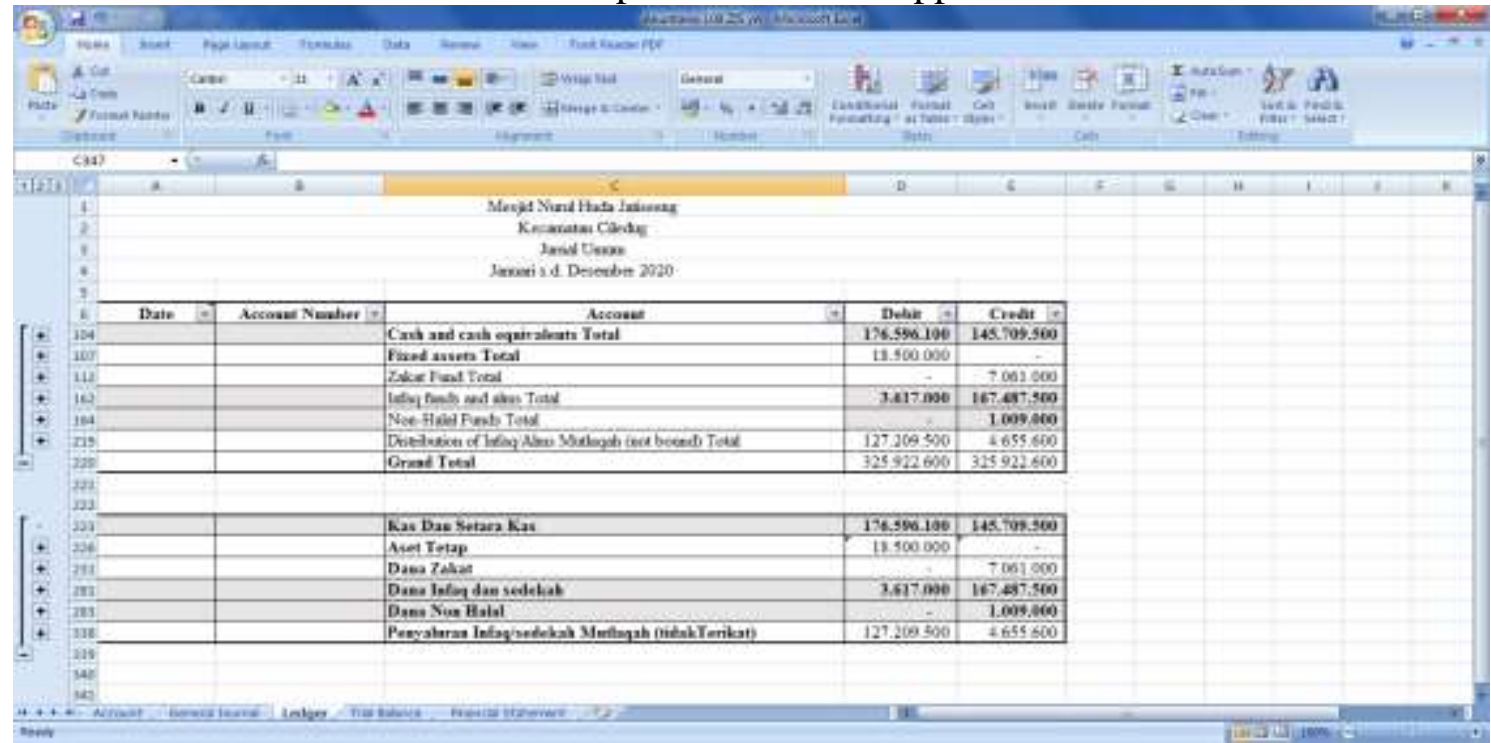

Figure 8 Ledger with Outline symbol 2

And if we click 3 it will show all the data in the ledger

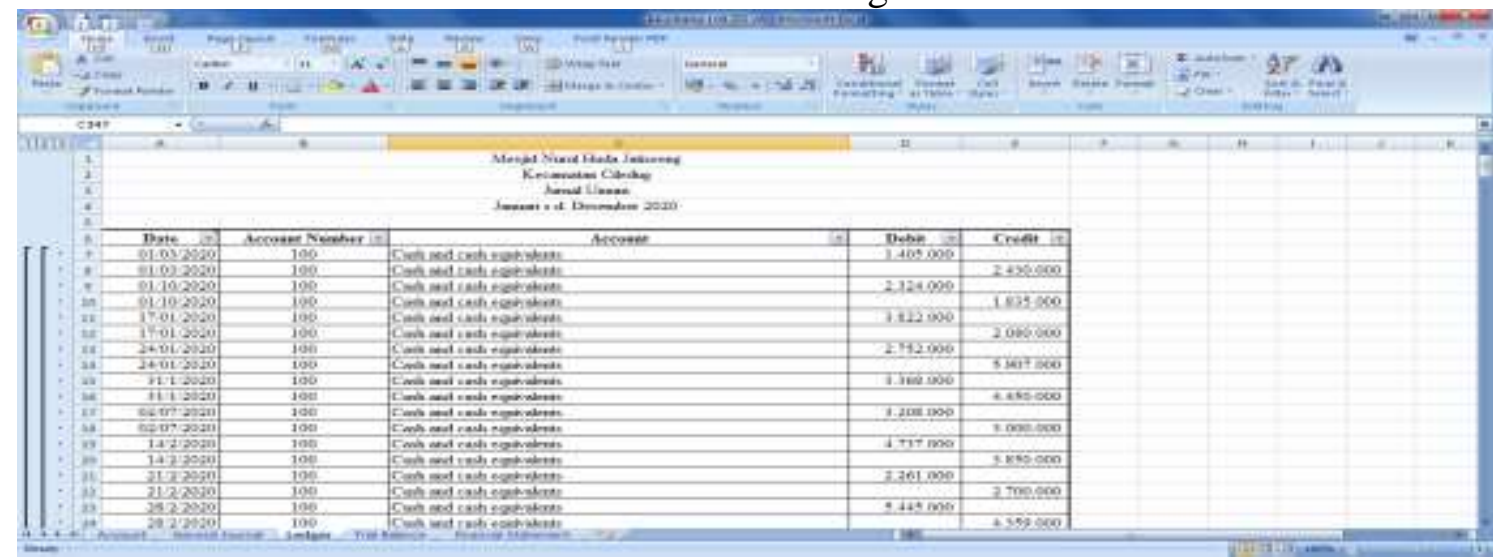

Figure 9 Ledger with Outline Symbol 3 
6. Creating a Trial Balance

The trial balance is a list containing the approximate balances of the general ledger that are systematically recorded by account number along with the number of debates and the number of credits concerned.(Fati G N Larosa \& Berupilihen br Ginting, 2009)

How to make a trial balance in the following order:

- Transaction column filling

Use the SUMIF formula and some range names contained in the ledger, namely: account, debit_ledger, and credit_ledger

Formula for debit column

=SUMIF(Account_Ledger, B7, Debit_Ledger)

Formula For Credit Column

= SUMIF(Account_Ledger,B7,Credit_Ledger)

Fill in the balance column by:

Balance debit $=\mathbf{I F}(\mathbf{C} 7>\mathbf{D 7}, \mathbf{C} 7-\mathbf{D} 7, \mathbf{0})$

Credit balance $=\mathrm{IF}(\mathrm{D} 7>\mathrm{C} 7, \mathrm{D} 7-\mathrm{C} 7,0)$

The result of the previous formula will appear in the image below

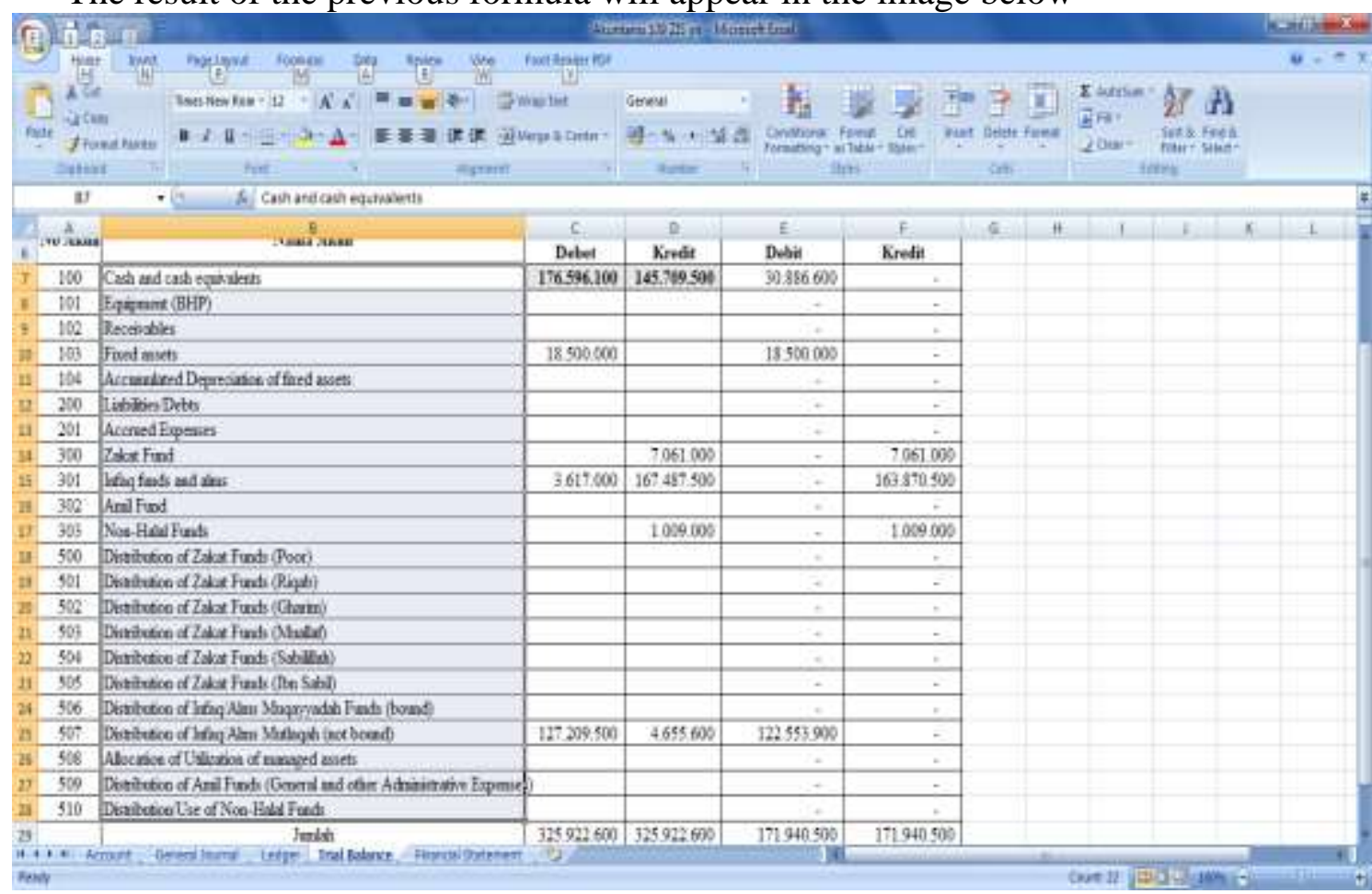

Figure 10 Trial Balance

7. Making financial reporting

Components of a complete financial report from the amil zakat agency or amil zakat institution according to PSAK 109 (IAI, 2010)

According to Statement of Financial Accounting Standards No. 1 concerning the presentation of financial statements, this Statement regulates the requirements for the presentation of financial statements, the structure of financial statements, and the minimum requirements for the contents of financial statements. An entity shall apply this Standard in the preparation and presentation of general purpose financial statements in accordance with SAK. This Statement does not 
apply to the preparation and presentation of the financial statements of Islamic entities. The components of a complete financial report consist of:

a. statement of financial position at the end of the period;

b. statement of profit or loss and other comprehensive income during the period;

c. statement of changes in equity during the period;

d. cash flow statement during the period;

e. notes to financial statements, containing a summary of significant accounting policies and other explanatory information;

(ea) comparative information about the prior immediate period as specified in paragraphs 38 and 38A; and

f. statement of financial position at the beginning of the nearest prior period when the entity applies an accounting policy retrospectively or makes a restatement of financial statement items, or when the entity reclassifies items in its financial statements in accordance with paragraphs 40A-40D.

An entity shall apply this Standard for financial year periods beginning on or after January 1, 2015. An entity shall apply the adjustment to paragraph 128 and prospectively for financial periods beginning on or after January 1, 2015. (Dewan Satndar Akuntansi Keuangan, 2014)

(Ikatan Akuntansi Indonesia, 2008) Balance sheet, reports on changes in funds, reports on changes in assets under management, cash flow statements, notes to financial statements components of a complete financial report of amil consist of:

a. balance sheet (statement of financial position)

b. fund change report

c. asset management report

d. cash flow statement

e. notes to financial statements

Table 1 Balance Sheet

Balance Sheet (Statement of Financial Position)

Mesjid Nurul Huda Jatiseeng Ciledug

As of 31 Desember 2020

\begin{tabular}{|l|l|l|l|}
\hline \multicolumn{1}{|c|}{ DESCRIPTION } & \multicolumn{1}{|c|}{ IDR } & \multicolumn{1}{c|}{ DESCRIPTION } & \multicolumn{1}{c|}{ IDR } \\
\hline $\begin{array}{l}\text { Cash anda cash } \\
\text { equivalents }\end{array}$ & $30,886,600$ & Liabilities & - \\
$\begin{array}{l}\text { Total Curent } \\
\text { Assets }\end{array}$ & $30,886,600$ & Total Liabilities & - \\
Total Fixed Asset & $18,500,000$ & Zakat Fund & $7,061,000$ \\
& & infaq fund and akm fund & $163,870,500$ \\
& & Amil Fund & - \\
Total Assets & $\mathbf{4 9 , 3 8 6 , 6 0 0}$ & Total Liabilities and Fund & $\mathbf{4 9 , 3 8 6 , 6 0 0}$ \\
\hline
\end{tabular}


Table 2

Fund Change Statement

Mesjid Nurul Huda Jatiseeng Ciledug

For the Period Ended 31 December 2020

\begin{tabular}{|l|r|}
\hline \multicolumn{1}{|c|}{ Description } & IDR \\
\hline Zakat Fund & 7.061 .000 \\
Receipt & 0 \\
Distribution & $\mathbf{7 . 0 6 1 . 0 0 0}$ \\
Surplus & \\
infaq fund and akm fund & 16.3870 .500 \\
Receipt & \\
Distribution & \\
Distribution of Infaq Fund and alms Fund (Not & 122.553 .900 \\
Board) & $\mathbf{4 1 . 3 1 6 . 6 0 0}$ \\
Surplus & \\
Amil Fund & \\
Receipt & \\
Distribution & 0 \\
Surplus/Defisit & \\
Non Halal Fund & \\
Receipt & \\
Distribution & $\mathbf{1 . 0 0 9 . 0 0 0}$ \\
Surplus & \\
End Balance & $\mathbf{4 9 . 3 8 6 . 6 0 0}$ \\
\hline
\end{tabular}


Table 3

Cash Flow Statetment

Mesjid Nurul Huda Jertiseeng Ciledug

31 Desember 2020

\begin{tabular}{|c|c|c|}
\hline Cash Flow from Operating Activities & & \\
\hline Cash receipts from zakat funds & $7,061,000$ & \\
\hline Cash Receipts from infaq and alms funds & $163,870,500$ & \\
\hline Cash Receipts from amil funds & & \\
\hline Cash receipts from non-halal funds & $1,009,000$ & \\
\hline Distribution of Infaq/Alms Mutlaqah (not bound) & $122,553,900$ & \\
\hline Net cash flow from operating activities & & $49,386,600$ \\
\hline Cash Flow from Investing Activities & & \\
\hline acquisition of fixed assets & $18,500,000$ & \\
\hline Free Cash Flow from Investing activities & & $18,500,000$ \\
\hline Cash Flows from financing activities & & - \\
\hline Increase in Cash And Cash Equivalents & & $30,886,600$ \\
\hline Cash and Cash equivalents Beginning of the year & & - \\
\hline Year End Cash And Cash Equivalents & & $30,886,600$ \\
\hline
\end{tabular}

\section{CONCLUSIONS}

Given the nature of our business, perhaps it is no surprise that this software is so popular. During the first stages of accountancy training, it is likely you used Excel to initially keep track of figures. As a familiar product, used into day-to-day work. The use of excel for accounting will be very helpful for institutions, companies, or organizations to present information on financial statements that are generally accepted and applicable so that users of financial statements can read the movement of ratios on the finances of companies, institutions or organizations.

PSAK 109 is a standard or reference for every institution that carries out zakat, infaq, and shadaqoh management activities and for this presentation the researcher applies it using Microsoft excel to make it easier to work and be efficient and precise and accurate.

Statement of Financial Accounting Standards 101: Presentation of Islamic Financial Statements (hereinafter referred to as PSAK 101) establishes the basis for presentation of general purpose financial statements for Islamic entities. This statement stipulates the requirements for the presentation of financial statements, the structure of 
the financial statements, and the minimum requirements for the content of the financial statements for sharia transactions. PSAK 101 provides an explanation of the general characteristics of Islamic financial statements, including those related to:

- Fair presentation and compliance with SAK;

- Accrual basis;

- Materiality and incorporation;

- Delete each other;

- Frequency of reporting;

- comparative information; and

- Presentation Consistency

PSAK 101 also provides a description of the structure and content of Islamic financial statements, including:

- Statement of Financial Position

- Statement of Income and Other Comprehensive Income

Statement of Changes in Equity

- Cash flow statement

- Notes to Financial Statements

To make it easier for users to apply the provisions for presenting sharia financial statements based on PSAK 101, PSAK 101 is equipped with illustrative examples of financial statements of sharia banks, sharia insurance entities, and amil. The attachments contained in PSAK 101 are an integral part of PSAK 101.

Conclusion for the Nurul Huda Jatiseeng Mosque

1. Nurul Huda Mosque in ZIS financial records still uses manuals and has not presented financial reporting according to PSAK 109, only presents a form of reporting with ordinary debit or credit bookkeeping or receipts and expenditures, without any accounting cycle work and some financial data has not been separated per type of transaction presented in the account. ,

2. There is no separation of receipts and disbursements of ZIS funds according to their designation so that all records are still mixed and not entered per component in accordance with PSAK 109 rules

3. recording of accounts payable that has not been well organized, so it cannot be known how much the amount of debt or receivables that occurred

4. There has not been a recording of the inventory of goods owned by the mosque obtained from donations and donors so that it is difficult to trace the assets owned by the mosque.

\section{Suggestion}

1. Make periodic financial reports per period to be able to provide financial information accurately and correctly as stipulated in PSAK 109 concerning Zakat, Infaq, Alms

2. There needs to be a good record of debt from receiving loans to recording payments and recording inventory of fixed assets owned by the mosque in detail so that it can be known how much the mosque's assets excluding cash and cash equivalents, and depreciation for fixed assets 
3. There is a need for a debt assistant record to record all liabilities

4. It is necessary to make an inventory of the goods owned by the mosque so that the assets owned by the mosque can be traced

Thank you very much we say to the directorate general of higher education, ministry ofeducation, culture, research and technology for the opportunity for me to get a research grant for a novice lecturer.

\section{REFERENCES}

Aditya, A. (2019). Analisis Penyusunan Laporan Keuangamn Organisasi Nirlaba Menggunakan Microsoft excel. Sustainability (Switzerland), 11(1), 1-14. http://dx.doi.org/10.1016

Agustin, M. (2016). Penggunaan microsoft excel dalam penyusunan laporan keuangan untuk meningkatkan kualitas informasi laporan keuangan. 4(1).

Amelia, E., \& Qibtiyah, M. (2015). Perlakuan Akuntansi Zakat Berdasarkan PSAK 45 dan PSAK 109 Pada BAMUIS BNI. The Journal of Tauhidinomics, 1(2), 183-198.

Ati Retna Sari, Delia Nurbatin, S. W. (2017). Aluntansi Keuangan Berbasis PSAK. Mitra Wacana Media.

Boedi Abdullah, B. A. S. (2014). Metode Penelitian Ekonomi Islam. CV Pustaka Setia.

Dewan Satndar Akuntansi Keuangan, D. (2014). PSAK Nomor 1 Tentang Penyajian Laporan Keuangan. Ikatan Akuntansi Indonesia.

Di, K., \& Kabupaten, B. (2021). Organisasi Pengelola Zakat (OPZ) merupakan lembaga 20/03/2021 pengelola zakat yang diberikan kepercayaan untuk dapat. 1(2), 99-110.

Elvinda Febry Angraeni. (2016). PENERAPAN AKUNTANSI ZAKAT DAN INFAK/SEDEKAH BERDASARKAN PSAK 109. Jurnal Ekonomi Bisnis Dan Manajemen, 4. https://ejournal.unsrat.ac.id/index.php/emba/article/view/15257

Fati G N Larosa \& Berupilihen br Ginting. (2009). Microsoft Excel For Accounting Cycle. CV Andi Offset.

Hadijah, S. (2019). Analisis Penerapan PSAK 109 Tentang Akuntansi Zakat, Infaq, dan Sedekah pada Badan Amil Zakat Nasional Kabupaten Majene. Journal of Economic, Public, and Accounting (JEPA), 1(2), 58-67. https://doi.org/10.31605/jepa.v1i2.297

Hamizar. (2012). Aplikasi Excel Untuk Akuntansi. Penerbit Lentera Ilmu.

Herry. (2014). Mahir Accounting Principles. Grasindo.

IAI. (2010). PSAK 109.

Ikatan Akuntansi Indonesia. (2008). ED.PSAK 109. DEwan Standar Akuntansi Keuangan.

Judhia, F. (2009). Pemanfaatan Microsoft Excel Dalam Pembuatan Laporan Keuangan. Media Informatika, 8(1), 28-42.

Kieso, D. E. (2010). Intermediate Accounting IFRS (1st ed.). JOhn Willey and sons.

M Irfan Firdausy. (2002). Zakat Profesi: Wacana Pemikiran dalam Fiqih Kontemporer. Cemerlang.

Muhajirin, A. L. (2020). Jurnal Ekonomika dan Bisnis Islam E-ISSN: 2686 - 620X Halaman 210 - 220. 3, 210-220.

Muhammad sanusi. (2009). Zakat Profesi: Wacana Pemikiran dalam Fiqih Kontemporer. salemba Diniyah. 
QS AliImran 134. (n.d.). Al Qur'an.

QS AT Taubah 103. (n.d.). Al Qur'an.

Rahman, T. (2015). AKUNTANSI ZAKAT, INFAK DAN SEDEKAH (PSAK 109): Upaya Peningkatan Transparansi dan Akuntabilitas Organisasi Pengelola Zakat (OPZ). Muqtasid: Jurnal Ekonomi Dan Perbankan Syariah, 6(1), 141. https://doi.org/10.18326/muqtasid.v6i1.141-164

Rudianto. (2012). Pengantar Akuntansi Konsep dan Teknik Penyusunan laporan Keuangan. Penerbit Erlangga.

Rully Indrawan, P. Y. (2014). Metodologi Penelitian Kuantitatif, Kualitatif, Dan Campuran. Refika Aditama.

Sofyan Syafri Harahap. (2011). Teiri Akuntansi. Pt Raja Grafindo Persada.

Sugiyono. (2019). Metode Penelitian Kuantitatif Kualitatif dan R\&D. Alfabeta.

UU No 23 RI. (2011). Undang Undang NO 23 Pengelolaan Zakat.

V. Wiratna Sujarweni. (2019). Metodologi Penelitian Bisnis Dan Ekonomi. PT Pustaka Baru.

Wasilah dan Sri Nurhayati. (2017). Akuntansi Syariah. Salemba Empat Pusta Pelajar.

Wulansari, S. dwi, \& Setiawan, A. H. (2014). Analisis Peranan Dana Zakat Produktif Terhadap Perkembangan Usaha Mikro Mustahik ( Penerima Zakat ). Diponegoro Journal of Economics, 3(1), 1-15. https://ejournal-s1.undip.ac.id/index.php/jme

Yusuf, A. H. (2017). Dasar Dasar Akuntansi Jilid 1 (17th ed.). Bagian Penerbitan STIE YKPN.

Zakat, A., Psak, E. D., Cipta, H., \& Indonesia, I. A. (2008). Pernyataan ini berlaku untuk amil yang menerima dan menyalurkan zakat dan infak/sedekah. 03. (Issue 109). 